\title{
EFFECT OF ROCK POWDER AND VINASSE ON TWO TYPES OF $\operatorname{SOILS}^{(1)}$
}

\author{
Otavio Mitsuhiro Motizuki Lopes ${ }^{(2)}$, Elma Neide Vasconcelos Martins Carrilho ${ }^{(3)}$ \& Maria \\ Leonor Ribeiro Casimiro Lopes-Assad ${ }^{(4)}$
}

\begin{abstract}
SUMMARY
Can vinasse accelerate the change of minerals in rock dust to obtain fertilizers, using residues from alcohol agro-industries and mining? Answering this question was the main objective of this study. Therefore, an experiment was set up in the laboratory in a completely randomized design using Polyvinyl Chloride (PVC) columns, in which the 0-50 cm layers of a clayey soil (eutroferric Red Oxisol) and sandy soil (Typic Quartzipsamment) were reproduced. We applied three different rates of basalt powder $\left(0.0 ; 2.0\right.$, and $\left.4.0 \mathrm{t} \mathrm{ha}^{-1}\right)$ and one rate of vinasse $\left(200 \mathrm{~m}^{3} \mathrm{ha}^{-1}\right)$ to the soils. The control was made by treatments with water $\left(200 \mathrm{~m}^{3} \mathrm{ha}^{-1}\right)$ with the same rates of rock powder. Samples were first collected on the surface of each column $(1,15,30,45,60$, and 90 days after the application of vinasse and rock powder), and, at the end of the experiment, at the various depths and in leached water, to determine $\mathrm{pH}$ and the concentration of soluble $\mathrm{Ca}^{2+}, \mathrm{Mg}^{2+}$, and $\mathrm{K}^{+}$. There was a significant effect of the solvent and the soil on the surface layer, with higher concentrations found in the treatments with vinasse and in clayey soil, confirming the potential of vinasse to alter minerals in basalt powder. The resulting levels from the beginning to the end of the experiment suggest that sorption phenomena with neoformed mineral phases or organic acids may have occurred. It may be concluded that the use of rock powder and vinasse mixtures is a promising alternative for soil fertilization and recycling of waste from the sugarcane and mining industries.
\end{abstract}

Index terms: basalt powder, $\mathrm{pH}$, cation availability, reuse of waste.

(1) Part of the first author's Master's Dissertation in the Graduate Studies Course in Agriculture and Environment (Programa de Pós-Graduação em Agricultura e Ambiente - PPGAA). Study funded by a FINEP project (FINEP Process 0944/08). Received for publication on Aug 26, 2013 and approved on July 25, 2014.

(2) Master's degree in Agriculture and Environment, Agrarian Sciences Center, Universidade Federal de São Carlos - UFSCar. Rodovia Anhanguera, km 174. CEP 13600-970 Araras (SP), Brazil. CAPES grant holder. E-mail: otaviomlopes@gmail.com

(3) Professor, Agrarian Sciences Center, UFSCar. E-mail: elma.carrilho@gmail.com

(4) Professor, Agrarian Sciences Center, UFSCar. CNPq grant holder. E-mail: assad@cca.ufscar.br 


\title{
RESUMO: EFEITO DE PÓ DE ROCHA E VINHAÇA EMDOIS TIPOS DE SOLOS
}

\begin{abstract}
A vinhaça pode acelerar a alteração de minerais em pó de rocha para obtenção de fertilizantes, com aproveitamento de residuos de agroindústrias de álcool e de mineradoras? Responder a esta pergunta foi o principal objetivo deste estudo. Assim, foi montado em laboratório um experimento no delineamento inteiramente casualizado em colunas de PVC, onde se reproduziram as camadas de $0-50 \mathrm{~cm}$ de um solo argiloso (Latossolo Vermelho muito argiloso) e de um solo arenoso (Neossolo Quartzarênico). Aos solos, foram adicionadas três doses de pó de basalto (0; 2,0; e 4,0 tha-1) e uma dose de vinhaça (200 $\left.\mathrm{m}^{3} \mathrm{ha}^{-1}\right)$. O controle foi feito por meio de tratamentos com água $\left(200 \mathrm{~m}^{3} \mathrm{ha}^{-1}\right)$ e com as mesmas doses de pó de rocha. Foram coletadas amostras na superfície de cada coluna (1, 15, 30, 45, 60 e 90 dias após a aplicação da vinhaça e do pó de rocha) e, ao final do experimento, em profundidade e no lixiviado, para determinar o $\mathrm{pH}$ e os teores solúveis de $\mathrm{Ca}^{2+}, \mathrm{Mg}^{2+}$ e $\mathrm{K}^{+}$. Houve efeito significativo do solvente e do solo, na camada superficial, com maiores teores nos tratamentos com vinhaça e no solo argiloso, confirmando o potencial da vinhaça para alterar minerais contidos no pó de basalto. No balanço de teores no início e no fim do experimento, os resultados sugeriram que fenômenos de sorção com fases minerais neoformadas ou com ácidos orgânicos podem ter ocorrido. Concluiu-se que o uso de mistura de pó de rocha e vinhaça é uma alternativa promissora para a adubação de solos e para o reaproveitamento de resíduos da indústria sucroalcooleira e de mineradoras.
\end{abstract}

Termos de indexação: pó de basalto, pH, cátions disponíveis, reaproveitamento de resíduos.

\section{INTRODUCTION}

The use of rock powders in soil fertilization was initially proposed by Julius Hensel in 1984 in the book Bread from Stones, where the author outlined the benefits of the use of ground rocks in agriculture, known as stone meal or remineralization of soils. Forgotten over decades, a recent increase in the use of stone meal in agriculture has been observed in various studies that evaluate the effects of rock powders in soils (Lourenço Júnior, 2011; Welter et al., 2011; Camargo et al., 2012; Melo et al., 2012; Silva et al., 2012).

Reactions between minerals and the soil solution include dissolution (congruent or incongruent), oxidation, complexation reactions, hydrolysis, and simple hydration. Silicate stone meal was generally used, for which the alteration reactions tended to be predominantly incongruent, i.e., the elements are not released from the solution in the same stoichiometric proportion as their initial composition and part of the products precipitated forms a new mineral (Kämpf et al., 2009).

The $\mathrm{pH}$ of the soil solution is the main factor that determines weathering rates. The function of $\mathrm{pH}$ in the dissolution of minerals is related to the adsorption of $\mathrm{H}^{+}$and $\mathrm{OH}^{-}$ions on the surface of minerals, where hydrolysis is controlled by acid-base reactions and oxygen-metal linkages (Ribeiro et al., 2010). Reactions between minerals and an acidic soil solution change the concentrations of $\mathrm{H}^{+}$ions and other dissolved species in the soil solution (Harley \& Gilkes, 2000). In the in vitro experiment conducted by Lopes et al. (2011), the effect of vinasse on the solubilization of minerals contained in mafic rock was evaluated. Different application rates of rock powder were evaluated in both vinasse and distilled water in the laboratory. After t30 days, the authors observed a lack of vinasse effect on the $\mathrm{pH}$ of the mixture, although there was greater nutrient availability in the vinasse treatment compared with the control and increased release of nutrients over time. In another experiment, Lopes (2013) tested the mode of vinasse application in sandy and clayey soils over 30 days and concluded that basalt powder incubated in vinasse for $24 \mathrm{~h}$ applied to soil did not present significant differences in the levels of soluble cations measured when compared with direct vinasse and rock powder application to the soil.

As soil is a complex system with high buffering capacity, it is estimated that mixtures of vinasse and rock powder behave differently from in vitro assays. Therefore, the objective of this study was to evaluate the effect of vinasse and basalt powder mixtures on $\mathrm{pH}$ and $\mathrm{Ca}, \mathrm{Mg}$, and $\mathrm{K}$ availability in two types of soil, a clayey soil and a sandy soil.

\section{MATERIALS AND METHODS}

The experiment was conducted in soil columns in the Soil and Mineralogy Laboratory of the Agrarian Sciences Center (Centro de Ciências Agrárias) at the Federal University of São Carlos (Universidade Federal de São Carlos) in Araras, São Paulo, from September to November 2012. The basalt powder used was collected from a residue pile from gravel production at a quarry in Cordeirópolis, São Paulo. In the mining, basalt residue less than $2 \mathrm{~mm}$ in diameter was collected and sieved to obtain materials less than or equal to $0.3 \mathrm{~mm}$ in diameter. Elemental analysis of this powder 
was carried out by atomic absorption spectrometry and presented the following results: $50.31 \% \mathrm{SiO}_{2}$, $13.94 \% \mathrm{Al}_{2} \mathrm{O}_{3}, 12.62 \% \mathrm{Fe}_{2} \mathrm{O}_{3}, 10.16 \% \mathrm{CaO}, 6.91 \%$ $\mathrm{MgO}, 2.24 \% \mathrm{Na}_{2} \mathrm{O}, 0.84 \% \mathrm{~K}_{2} \mathrm{O}$, and $0.09 \% \mathrm{P}_{2} \mathrm{O}_{5}$.

The vinasse used was provided from molasse of a sugarcane-ethanol industry located in Piracicaba, São Paulo, showing the following chemical composition: $\mathrm{pH} 4.2,21.83 \mathrm{~g} \mathrm{dm}^{-3} \mathrm{C}, 0.62 \mathrm{~g} \mathrm{dm}^{-3} \mathrm{~N}, 581 \mathrm{mg} \mathrm{dm}^{-3} \mathrm{Fe}$, $313.1 \mathrm{mg} \mathrm{dm}^{-3} \mathrm{Mn}, 92.2 \mathrm{mg} \mathrm{dm}^{-3} \mathrm{SO}_{4}, 54.2 \mathrm{mg} \mathrm{dm}^{-3}$ $\mathrm{Zn}, 30 \mathrm{mg} \mathrm{dm}{ }^{-3} \mathrm{Cu}, 110 \mathrm{mmol}_{\mathrm{c}} \mathrm{dm}^{-3} \mathrm{~K}_{2} \mathrm{O}, 53.6 \mathrm{mmol}_{\mathrm{c}}$ $\mathrm{dm}^{-3} \mathrm{CaO}, 25.1 \mathrm{mmol}_{\mathrm{c}} \mathrm{dm}^{-3} \mathrm{MgO}$, and $4.23 \mathrm{mmol}_{\mathrm{c}} \mathrm{dm}^{-3}$ $\mathrm{P}_{2} \mathrm{O}$. Vinasse was kept frozen until its utilization. Organic acids in vinasse samples (triplicate) were determined by high performance liquid chromatography (HPLC) with a diode array detector (DAD). Water soluble organic substances were extracted from vinasse by shaking of the sample at $200 \mathrm{rpm}$ for $1 \mathrm{~h}$, after which the supernatant was separated and centrifuged at $3000 \mathrm{rpm}$ for $10 \mathrm{~min}$. The resulting supernatant was evaporated to reduce the volume, and the residue was dissolved in methanol for identification of aliphatic organic acids by HPLC. In an attempt to eliminate interferences, the samples were treated in advance with polyvinyl polypyrrolidone (PVPP), centrifuged, and filtered in $0.20 \mu \mathrm{m}$ CHROMAFIL $®$ filters to separate solid particles of potential interference. The resulting material was diluted to 1:50 to avoid overlapping peaks and to reduce interference. The separation was carried out in a $\mathrm{C} 18$ chromatographic column and $0.005 \mathrm{~mol} \mathrm{~L}^{-1} \mathrm{H}_{2} \mathrm{SO}_{4}$ as the mobile phase. Organic acids were identified by comparison of the retention time of each substance in the sample and those of the analytical standards shown in the chromatogram obtained. The absorption spectrum of each HPLC peak was run from 190 to $500 \mathrm{~nm}$ to select the most appropriate wavelength around $210 \mathrm{~nm}$.

Two soil types were used: a Latossolo Vermelho eutrófico (eutroferric Red Oxisol) (clayey soil) and a Neossolo Quartzarênico (Typic Quartzipsamment) (sandy soil), classified according to the Brazilian System of Soil Classification (Embrapa, 2013). The clayey soil was collected at the Agrarian Sciences Center at UFSCar and the sandy soil was from Leme, São Paulo. In both places trenches were opened and soil material was collected in two layers (0-20 and 20-50 cm depth) to ensure representation of topsoil and subsoil horizons.

In soil collection, disturbed and undisturbed samples $\left(50 \mathrm{~cm}^{3}\right.$ volume sampling ring) were extracted from every $10 \mathrm{~cm}$ of soil depth to $50 \mathrm{~cm}$, in three replications. In disturbed samples, $\mathrm{pH}$ was determined in calcium chloride, and the levels of organic matter (OM), $\mathrm{Ca}, \mathrm{Mg}, \mathrm{K}$, sand (2-0.5 mm), silt (0.05-0.002 $\mathrm{mm})$, and clay $(<0.002 \mathrm{~mm}$ ) according to Raij et al. (2001). In undisturbed samples, specific mass was defined according to Camargo et al. (2009). Mean values for the $0-20 \mathrm{~cm}$ and $20-50 \mathrm{~cm}$ depth layers were calculated from the mean of three replications of the respective sub-layers (Table 1 ).

Polyvinyl chloride (PVC) tubing columns of $0.67 \mathrm{~m}$ height and $0.19 \mathrm{~m}$ inner diameter were set up in an arrangement adapted from Casagrande \& Soares (2009). Each column was closed at the base with a PVC cover, in which an adapter was placed to collect leached solute from the soil. To prevent soil loss during the leaching process, five successive layers were placed from the bottom up to $10 \mathrm{~cm}$ from the base as follows: expanded clay, nylon screen, expanded clay, multipurpose cloth, and nylon screen. In each column, $50 \mathrm{~cm}$ of soil were added, divided into two parts according to the layers collected $(0-20$ and $20-50 \mathrm{~cm}$ deep). Columns were filled with air-dried soil (ADS), previously passed through a $2 \mathrm{~mm}$ soil sieve. The soil amount added was calculated based on the volume of each tube and on the soil density of the layers where the material was collected.

The experiment consisted of 12 treatments, with three replications, using 18 columns of clayey soil and 18 columns of sandy soil. The application of $200 \mathrm{~m}^{3} \mathrm{ha}^{-1}$ of vinasse (rate generally applied on the sugarcane crop) or water, as control, and rates of $2 \mathrm{t} \mathrm{ha}^{-1}$ and $4 \mathrm{t} \mathrm{ha}{ }^{1}$ of rock powder were tested. Thus, $0.57 \mathrm{~L}$ of vinasse or distilled water and $5.67 \mathrm{~g}$ and $11.34 \mathrm{~g}$ of rock powder were applied as treatments. The treatments were as follows: $200 \mathrm{~m}^{3} \mathrm{ha}^{-1}$ vinasse $+2 \mathrm{t} \mathrm{ha}^{-1}$ basalt powder + clayey soil (T1), $200 \mathrm{~m}^{3} \mathrm{ha}^{-1}$ vinasse $+4 \mathrm{t} \mathrm{ha}^{-1}$ basalt powder + clayey soil (T2), $200 \mathrm{~m}^{3} \mathrm{ha}^{-1}$ vinasse $+2 \mathrm{t} \mathrm{ha}^{-1}$ basalt powder + sandy soil (T3), $200 \mathrm{~m}^{3} \mathrm{ha}^{-1}$ vinasse $+4 \mathrm{t} \mathrm{ha}^{-1}$ basalt powder + sandy soil (T4), $200 \mathrm{~m}^{3} \mathrm{ha}^{-1}$ distilled water + clayey soil (T5), $200 \mathrm{~m}^{3} \mathrm{ha}^{-1}$ distilled water + sandy soil (T6), $200 \mathrm{~m}^{3} \mathrm{ha}^{-1}$ distilled water $+2 \mathrm{t} \mathrm{ha}^{-1}$ basalt powder + clayey soil (T7), $200 \mathrm{~m}^{3} \mathrm{ha}^{-1}$ distilled water $+4 \mathrm{t} \mathrm{ha}^{-1}$ basalt powder + clayey soil (T8), $200 \mathrm{~m}^{3} \mathrm{ha}^{-1}$ distilled water $+2 \mathrm{t} \mathrm{ha}^{-1}$ basalt powder + sandy soil (T9), $200 \mathrm{~m}^{3} \mathrm{ha}^{-1}$ distilled water $+4 \mathrm{t} \mathrm{ha}^{-1}$ basalt powder + sandy soil (T10), $200 \mathrm{~m}^{3} \mathrm{ha}^{-1}$ distilled water + clayey soil (T11), and $200 \mathrm{~m}^{3} \mathrm{ha}^{-1}$ distilled water + sandy soil (T12).

In the basalt powder treatments, the surface layer of the soil profile was collected after filling the 20-50 $\mathrm{cm}$ layer, in a quantity sufficient to fill $5 \mathrm{~cm}$ of the column. After that, the defined quantity of powder for each column was mixed with soil material to fill the remaining $15 \mathrm{~cm}$, and distilled water or the vinasse treatment was applied.

The experiment was conducted for 90 days, and soil from the surface layer was collected at 1, 15, 30, 45,60 , and 90 days after water or vinasse application. Vinasse was applied once at the beginning of the experiment, while application rates of distilled water were applied in all columns throughout the experiment (including the one first treated with vinasse).

The amount of water and frequency of application were defined based on rainfall behavior from historical analysis of rainfall data in the Araras region. The 
Table 1. Chemical and physical characteristics of Latossolo Vermelho eutrófico (eutroferric Red Oxisol) (clayey soil) and Neossolo Quartzarênico (Typic Quartzipsamment) (sandy soil) subjected to vinasse and basalt powder treatments

\begin{tabular}{|c|c|c|c|c|c|c|c|c|c|}
\hline Depth & $\mathrm{pH}\left(\mathrm{CaCl}_{2}\right)$ & $O M^{(1)}$ & $\mathbf{K}$ & $\mathbf{C a}$ & $\mathrm{Mg}$ & Soil density & Area & Silt & Sand \\
\hline \multirow[t]{2}{*}{$\mathrm{cm}$} & & $\mathrm{g} \mathrm{dm}^{-3}$ & - & $\operatorname{nol}_{\mathrm{c}} \mathrm{d}$ & 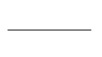 & $\mathrm{kg} \mathrm{dm} \mathrm{m}^{-3}$ & 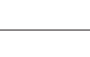 & $\mathrm{g} \mathrm{kg}^{-1}$ & 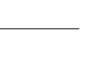 \\
\hline & \multicolumn{9}{|c|}{ Eutroferric Red Oxisol (clayey soil) } \\
\hline $0-20$ & 5.5 & 33.0 & 3.9 & 27.0 & 9.0 & 1.3 & 147 & 266 & 587 \\
\hline \multirow[t]{2}{*}{$20-50$} & 5.5 & 23.7 & 2.2 & 18.7 & 7.7 & 1.3 & 140 & 230 & 630 \\
\hline & \multicolumn{9}{|c|}{ Typic Quartzipsamment (sandy soil) } \\
\hline $0-20$ & 4.1 & 4.0 & 1.3 & 2.5 & 1.0 & 1.78 & 910 & 10 & 80 \\
\hline $20-50$ & 4.0 & 2.0 & 2.1 & 1.0 & 1.0 & 1.80 & 902 & 36 & 62 \\
\hline
\end{tabular}

(1) OM: organic matter.

months of November, December, and January were considered as the rainiest months in the region. Mean precipitations and number of rainy days in the towns/ cities in this region (Araras, Rio Claro, Leme, Limeira, Mogi Guaçu, and Conchal) were indicated by Agritempo, a Brazilian agrometeorological monitoring system (Sistema Agritempo, 2012). A precipitation level of $515 \mathrm{~mm}$ and frequency of 34 rainy days were simulated over the 90 days of the experiment, applying 10 to $20 \mathrm{~mm}$ of water at two to three day intervals.

Surface layers were collected up to $0.12 \mathrm{~m}$ using a spatula. At the end of the experiment, the columns were disassembled and a sample was taken from the 0.20-0.50 m soil layer. Samples of leached material were also collected from each column. The $\mathrm{pH}$ in $\mathrm{CaCl}_{2}$ and levels of $\mathrm{Ca}, \mathrm{Mg}$, and $\mathrm{K}$ were determined in soil samples, while soluble cation contents were determined in the solutes collected, according to Raij et al. (2001).

Data were analyzed by the Analysis of Variance (ANOVA) statistical method using a completely randomized split plot design, in which plots corresponded to treatments, blocks were the replications, and subplots corresponded to times. The means for each test time were compared by the ScottKnott test with a P-value of 0.05 . The behavior of each attribute in response to testing time was evaluated by regression analysis considering the division of dual interactions (soil, solvent, application rate) in ANOVA and fitting equations. Statistical analysis was made using SAS Version 9.3 (SAS, 2011).

\section{RESULTS AND DISCUSSION}

Figure 1 depicts the chromatograms of a mixture of standard and vinasse samples. These indicate the presence of citric, malic, succinic, and lactic acids. Figure 2 shows replicates of a chromatogram, at different separation times of this sample, in which other compounds seem to be co-eluting with the organic acids. These substances may significantly

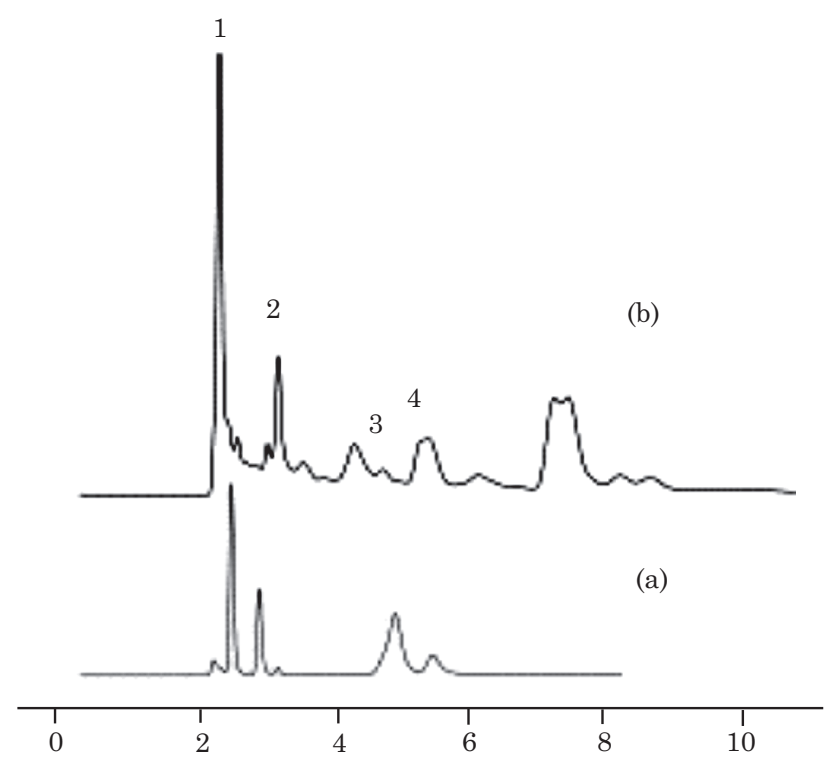

Figure 1. HPLC chromatograms of: (a) a mixture of standard solutions of organic acids, and (b) vinasse sample. Peaks identified: (1) malic acid, (2) lactic acid, (3) citric acid, and (4) succinic acid.

interfere with identification of the acids investigated and there may also be other non-identified organic acids in the vinasse sample.

Attempts were made to minimize the effect of interferences, including decrease of the mobile phase flow rate and diluting the sample. However, no increases in chromatographic separation were observed. Nevertheless, interferents were found among the acids eluted, citric $\left(\mathrm{C}_{6} \mathrm{H}_{8} \mathrm{O}_{7}\right.$, tricarboxylic), malic $\left(\mathrm{C}_{4} \mathrm{H}_{6} \mathrm{O}_{5}\right.$, dicarboxylic), succinic $\left(\mathrm{C}_{4} \mathrm{H}_{6} \mathrm{O}_{4}\right.$, dicarboxylic) and lactic $\left(\mathrm{C}_{3} \mathrm{H}_{6} \mathrm{O}_{3}\right.$, monocarboxylic) acids in the vinasse sample were identified by the retention times of the analytical standards.

The chromatograms generated at different times allowed the presence of a variety of compounds to be seen, indicated by the presence of several peaks. They indicate the presence of organic acids in the vinasse 

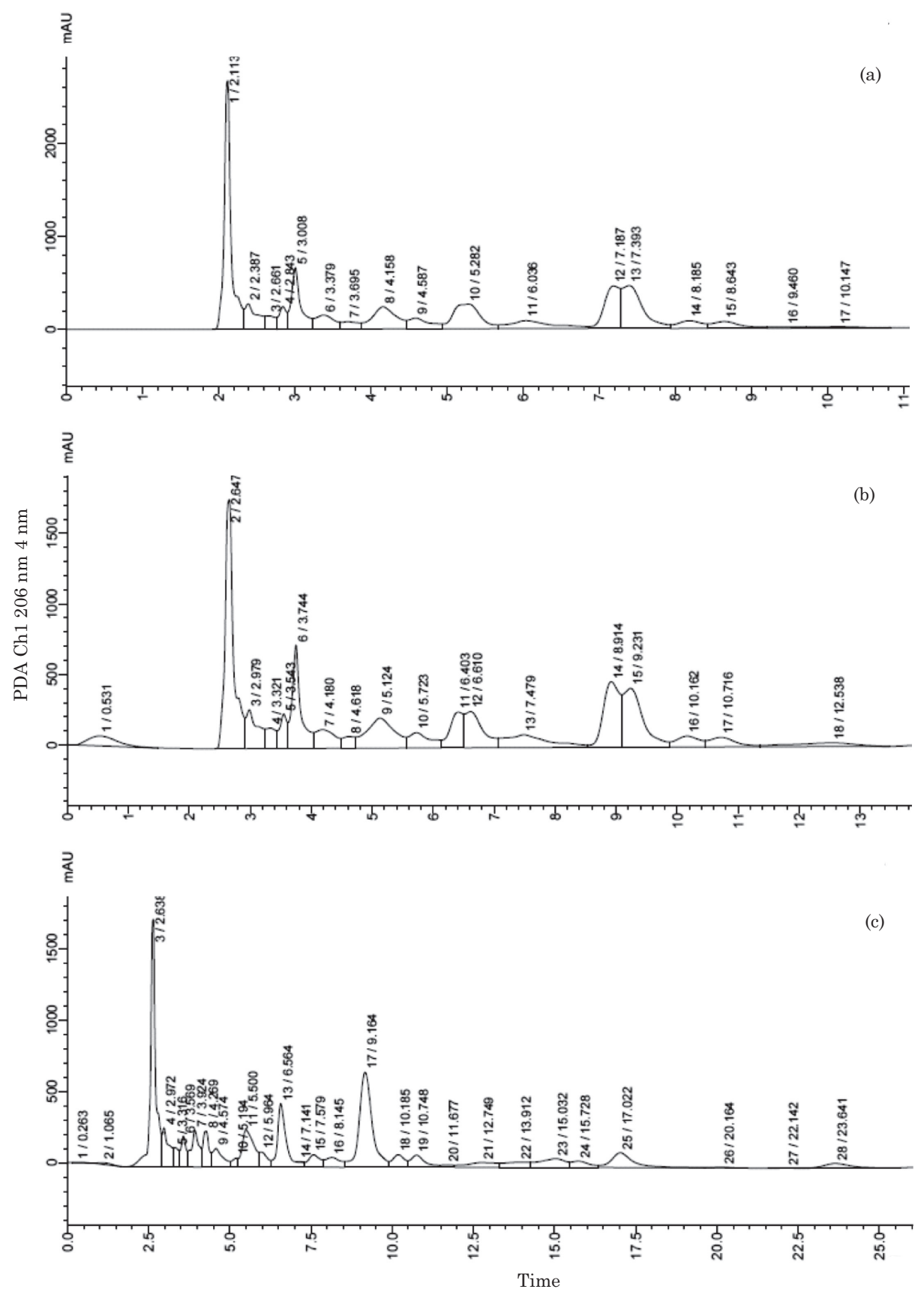

Figure 2. Chromatograms of vinasse sample at different run times: (a) $11 \mathrm{~min}$, (b) $14 \mathrm{~min}$, and (c) $25 \mathrm{~min}$.

analyzed, as well as interferents that may also have been co-eluted, affecting the identification and quantification of these acids. The presence of these possible interferences may principally be due to the complexity of the vinasse composition. In order to overcome interferences and improve chromatographic separation, better sample preparation prior to analysis needs to be carried out. Therefore, further studies on the identification and quantification of organic acids in vinasse should be pursued in order to understand the role of these substances in the solubilization of minerals in rock powder.
Organic acids such as formic, acetic, and oxalic acids are weak complexants and their behavior is similar to diluted solutions of mineral acids and $\mathrm{CO}_{2}$ acidified water. They may accelerate the decomposition of soil minerals through complexation, which occurs when organic compounds bind to metallic ions (Kämpf et al., 2009). In phlogopite dissolution, for example, the percentage of elemental extraction is greater for oxalic, citric, tartaric, and salicylic acids than $\mathrm{HCl}$ and $\mathrm{H}_{2} \mathrm{SO}_{4}$ (Kämpf et al., 2009). Citric acid forms complexes preferentially with $\mathrm{Al}$, while malic acid has a preference for Ca (Pavinato \& Rosolem, 2008). 
Multifunctional organic acids, such as citric acid, are more efficient in the dissolution of silicates than monocarboxylic acids, such as lactic acid, due to their greater ability to complex cations and silica (McMahon et al., 1995).

Over the 90 experimental days, there was a significant effect of soil type on the levels of $\mathrm{Ca}^{2+}, \mathrm{Mg}^{2+}$ and $\mathrm{K}^{+}$cations (Table 2 ), confirming the potential of vinasse to alter the minerals in the basalt powder. The interaction of soil and basalt powder was significant for $\mathrm{pH}$ levels only (Table 2). The interactions between solvent and time (Figure 3a,c,e) and soil and time (Figure 3b,d,f) were significant for all the attributes, while the application rate and time interaction was not significant for any of the attributes evaluated (Table 2).

In the alteration of basalt, substantial nonhydrolysable cation losses $\left(\mathrm{Ca}^{2+}, \mathrm{Mg}^{2+}\right.$, and $\left.\mathrm{Na}^{+}\right)$and preservation of $\mathrm{Si}^{4+}, \mathrm{Al}^{3+}$, and $\mathrm{Fe}^{3+}$ generally occurred quickly (Rasmussen et al., 2010). These processes occurred at different rates according to the mineral group. Experiments reported by Yang et al. (2014) suggested that the dissolution rate of feldspar can be affected by the $\mathrm{pH}$, the degree of $\mathrm{Al} / \mathrm{Si}$ substitution, the composition chemistry of the sample, and the relative speed of hydrolysis. The pyroxenes, another group of minerals found in basalt, showed dissolution rates that continually decrease with the increase in $\mathrm{pH}$ and are slightly inhibited by the increase in bivalent metallic cation concentration (Gudbrandsson et al., 2011).

According to Harley \& Gilkes (2000), the dissolution of minerals involves two opposing forces, in which ions strongly link to the mineral competing with the hydration process. First, there is a rapid cation exchange reaction between the surface cations and the $\mathrm{H}^{+}$and $\mathrm{H}_{3} \mathrm{O}^{+}$ions or the water molecules. For greater dissolution to occur, structural elements are released by destruction of oxygen-metal and hydroxide-metal bonds. Thus, base cations may be involved, or detachment of an activated complex from the mineral surface may occur. The activated complex can be either a specific surface species or a surface complex involving a metal exposed at the surface of the solid and a ligand from solution (Harley \& Gilkes, 2000).

In the present study, the $\mathrm{pH}$ in calcium chloride varied slightly with time, and the clayey soil exhibited greater values than the sandy soil (Figure 4a). Silva et al. (2012) observed that an ultramafic rock (with mineralogical composition similar to basalt) provided an increase in $\mathrm{pH}$ proportional to the quantity of powder applied. In the present study, no effect of application rate was verified in any of the soils. However, a difference was observed in the effect of solvent with time (Figure 4b). The highest mean values of $\mathrm{pH}$ occurred in the vinasse treatments.

The behavior of all the attributes studied in the surface layer varied with time, to which were fitted mainly second and third degree polynomial equations. Decreases in cation values were observed without significant variation in $\mathrm{pH}$ in either soil, suggesting a leaching process in the topsoil horizon. Indeed, in the $20-50 \mathrm{~cm}$ soil layer, the soils presented no difference in $\mathrm{pH}$ in regard to initial $\mathrm{pH}$ value, but changes were observed in soluble cations (Table 3).

There was a significant increase in $\mathrm{Ca}^{2+}$ and $\mathrm{Mg}^{2+}$ at greater depth in the clayey soil, while in the sandy soil there was an increase in $\mathrm{Mg}^{2+}$ cations, and the $\mathrm{Ca}^{2+}$ concentrations remained statistically equal (Table $3)$. Meanwhile, when vinasse was present, the $\mathrm{K}^{+}$ levels were significantly higher than distilled water, and the initial $\mathrm{K}^{+}$value decreased with all treatments in the sandy soil (Table 3).

In leaching, the presence of soluble cations was observed for all treatments, with emphasis on the presence of $\mathrm{K}^{+}$in the sandy soil treated with vinasse, regardless of whether basalt powder was used (Table 3 ). The soil texture and amount of cations present in the vinasse only partially explained the results obtained. The movement of solutes in the soil depended on factors such as soil type, mineralogy, cation exchange capacity, species of cations absorbed, percolation speed, level of organic matter, and the $\mathrm{pH}$ of the medium. As the solid phase of the soil interacted with the ions in solution (adsorption), their transport was delayed compared to water.

Some studies noted that vinasse can promote soil cation movements and it seems that rock powder can interfere in this process. Matos et al. (2013) attempted to evaluate the retardant factor of $\mathrm{Ca}^{2+}, \mathrm{Mg}^{2+}$, and $\mathrm{K}^{+}$ movement present in vinasse in three soil types, and they observed that the highest values of the retardant factor were obtained for $\mathrm{K}^{+}$in dystrophic Red Oxisol, followed by $\mathrm{Ca}^{2+}$ in dystrophic Red-Yellow Oxisol, and finally for $\mathrm{K}^{+}$in dystrophic Red-Yellow Oxisol. The lowest retardant factors for the cations evaluated were found in eutroferric Red Oxisol, while $\mathrm{Mg}^{2+}$ exhibited low retardant factors in all soils. In the present study, the data obtained did not show effects from application rate except for $\mathrm{K}^{+}$at the highest application rate of rock powder.

The balance of soluble cation levels between the beginning and the end of the experiment was generated from soluble cation levels measured at the topsoil and subsoil layers and in the leached solute, considering a closed system without cation exportation (Table 3). It was observed that the treatments with basalt powder and distilled water showed an increase in available $\mathrm{Ca}^{2+}, \mathrm{Mg}^{2+}$ and $\mathrm{K}^{+}$. In the presence of water and rock powder, the increases in $\mathrm{Ca}^{2+}$ and $\mathrm{Mg}^{2+}$ levels were proportional to the rate of basalt powder applied in both soils studied. For the $\mathrm{K}^{+}$levels, the increase was only proportional to the application rate of rock powder in the clayey soil. In the sandy soil, the increase in the $\mathrm{K}^{+}$levels was null or practically null at both rates applied. 
Table 2. Probabilities of significance for the plot and subplot interactions in the experiment

\begin{tabular}{|c|c|c|c|c|}
\hline Variation factor & $\mathrm{pH}\left(\mathrm{CaCl}_{2}\right)$ & $\mathbf{K}$ & $\mathrm{Ca}^{2+}$ & $\mathrm{Mg}^{2+}$ \\
\hline & & Plot & & \\
\hline Soil & $<0.0001^{* * *}$ & $<0.0001^{* * *}$ & $<0.0001^{* * *}$ & $<0.0001^{* * *}$ \\
\hline Solvent & $<0.0001^{* * *}$ & $<0.0001^{* * *}$ & $<0.0001^{* * *}$ & $<0.0001^{* * *}$ \\
\hline Application rate & $0.3462^{\mathrm{ns}}$ & $0.9949^{\mathrm{ns}}$ & $0.8645^{\mathrm{ns}}$ & $0.9379^{\mathrm{ns}}$ \\
\hline Soil $\times$ Solvent & $<0.0001^{* * *}$ & $<0.0001^{* * *}$ & $0.0005^{* *}$ & $0.2604^{\mathrm{ns}}$ \\
\hline Soil $\times$ application rate & $0.0402^{*}$ & $0.3486^{\mathrm{ns}}$ & $0.0082^{\mathrm{ns}}$ & $0.2142^{\mathrm{ns}}$ \\
\hline \multirow[t]{2}{*}{ Solvent $\times$ application rate } & $0.0692^{\mathrm{ns}}$ & $0.678^{\mathrm{ns}}$ & $0.6835^{\mathrm{ns}}$ & $0.4875^{\mathrm{ns}}$ \\
\hline & & Subplot & & \\
\hline Time & $<0.0001^{* * *}$ & $<0.0001^{* * *}$ & $<0.0001^{* * * *}$ & $<0.0001^{* * *}$ \\
\hline Soil $\times$ time & $<0.0001^{* * *}$ & $<0.0001^{* * *}$ & $<0.0001^{* * *}$ & $<0.0001^{* * *}$ \\
\hline Solvent $\times$ time & $<0.0001^{* * *}$ & $<0.0001^{* * * *}$ & $0.0004^{* *}$ & $<0.0001^{* * * *}$ \\
\hline Application rate $\times$ time & $0.2027^{\mathrm{ns}}$ & $0.3742^{\mathrm{ns}}$ & $0.9904^{\mathrm{ns}}$ & $0.9706^{\mathrm{ns}}$ \\
\hline
\end{tabular}

ns: not significant $(\mathrm{p}>0.05) ;{ }^{*}$ significant $(0.01<\mathrm{p}<0.05) ; * *$ highly significant $(0.001<\mathrm{p}<0.01) ; * * *$ extremely significant $(\mathrm{p}<0.001)$.

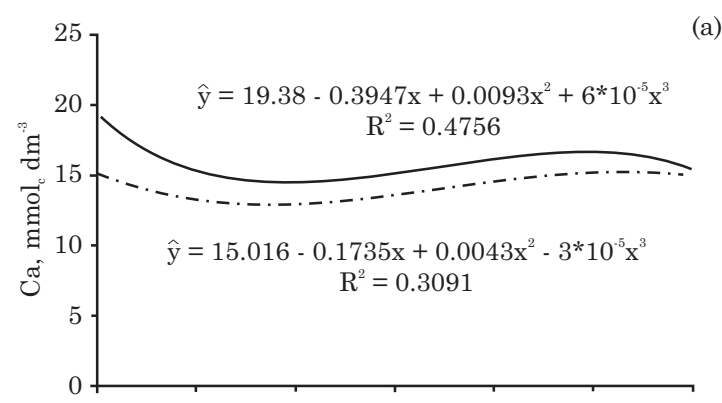

(a)
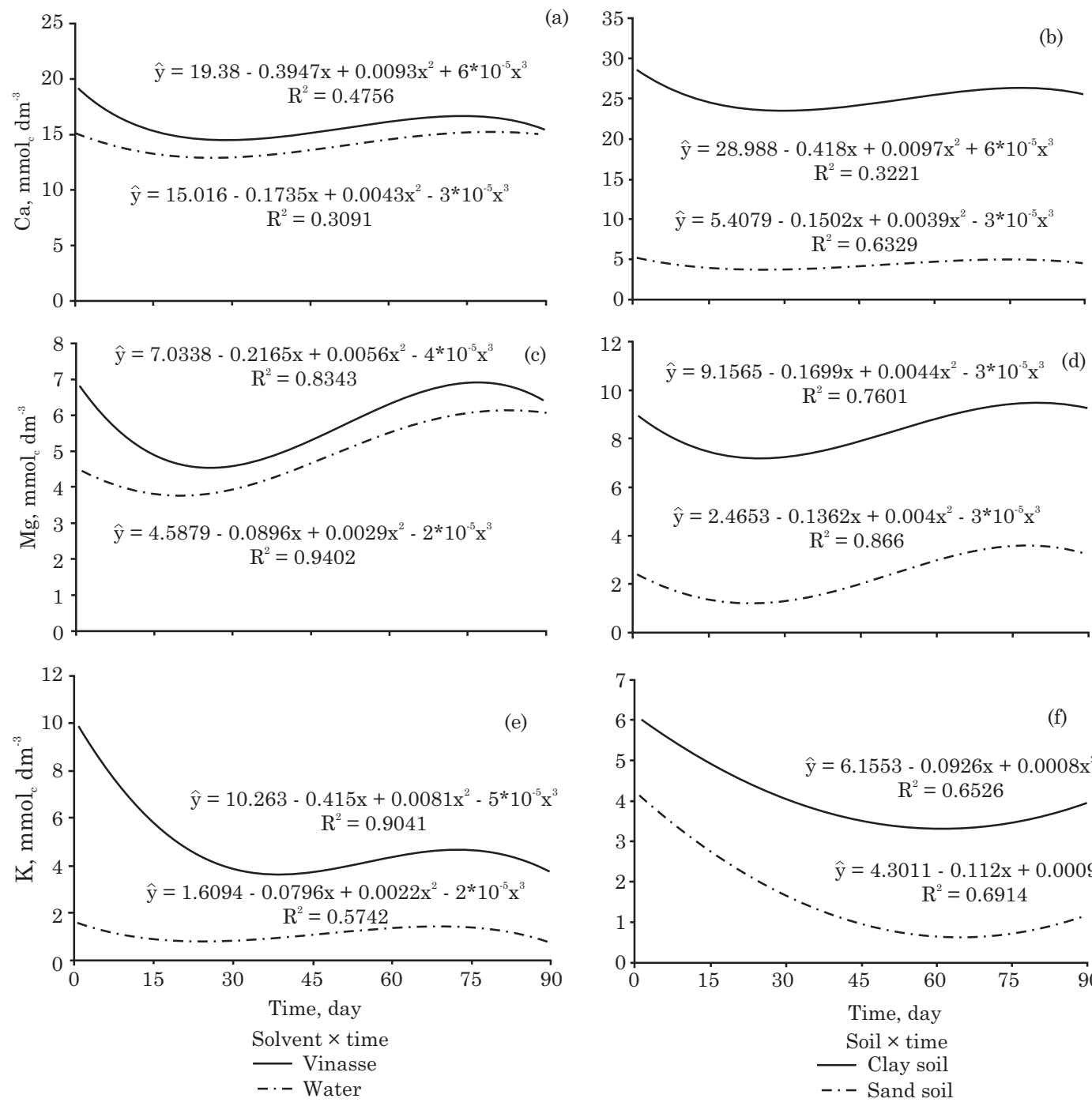

(b)
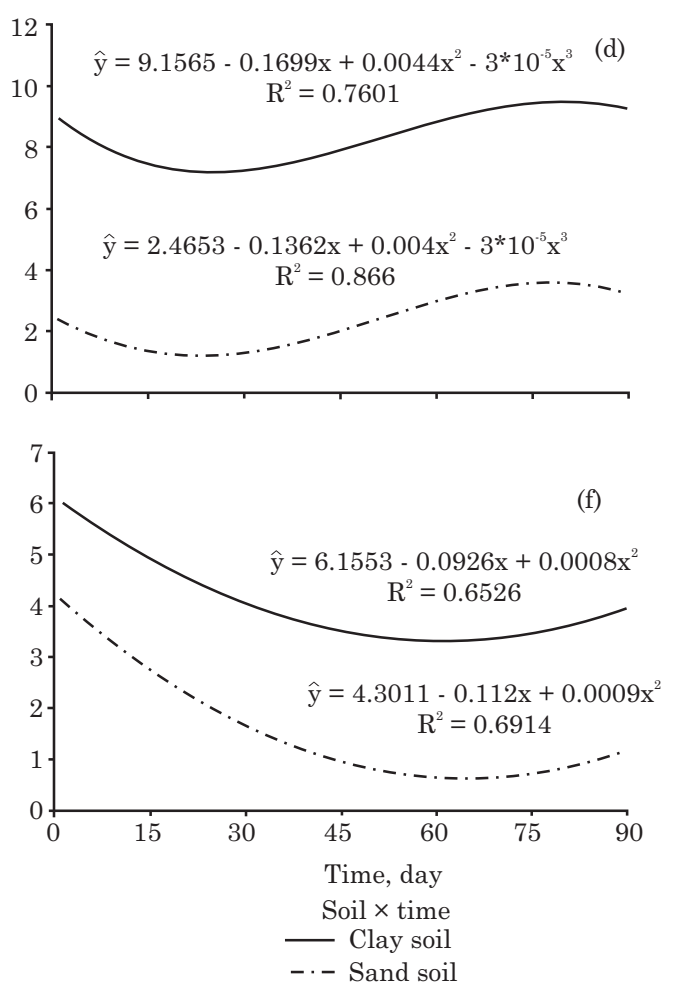

Figure 3. Effect of solvent for $\mathrm{Ca}(\mathrm{a}), \mathrm{Mg}$ (c) and $\mathrm{K}$ (e), and soil for $\mathrm{Ca}(\mathrm{b}), \mathrm{Mg}$ (d) and $\mathrm{K}$ (f) on the variation in macronutrient levels based on vinasse application and soil type (Red Oxisol - clayey soil, and Typic Quartzipsamment - sandy soil). 
Table 3. Cation concentration in samples collected in the $20-50 \mathrm{~cm}$ soil layer and leaching, and the balance of calcium $(\Delta \mathrm{Ca})$, magnesium $(\Delta \mathrm{Mg})$, and potassium $(\Delta \mathrm{K})$ levels after 90 days of experimental application of two rates of basalt powder (2T or 4T) and solvent (vinasse or water) in Red Oxisol (clayey soil) and Typic Quartzipsamment (sandy soil)

\begin{tabular}{|c|c|c|c|c|c|c|c|c|c|c|}
\hline \multirow{2}{*}{ Treatment } & \multicolumn{4}{|c|}{ Soil layer $(20-50 \mathrm{~cm})$} & \multicolumn{3}{|c|}{ Leaching } & \multirow{2}{*}{$\Delta \mathbf{C a}$} & \multirow{2}{*}{$\Delta \mathrm{Mg}$} & \multirow{2}{*}{$\Delta \mathrm{K}$} \\
\hline & $\mathrm{pH}\left(\mathrm{CaCl}_{2}\right)$ & $\mathrm{Ca}^{2+}$ & $\mathrm{Mg}^{2+}$ & $\mathbf{K}^{+}$ & $\mathrm{Ca}^{2+}$ & $\mathrm{Mg}^{2+}$ & $\mathbf{K}^{+}$ & & & \\
\hline & & & & & & $-\mathrm{mmo}$ & $\mathrm{dm}^{-3}$ & & & \\
\hline Vinasse $+2 \mathrm{~T}+$ clayey soil & $5.47 \mathrm{a}$ & $27.49 \mathrm{a}$ & $9.45 \mathrm{a}$ & $4.03 \mathrm{a}$ & $14.5 \mathrm{a}$ & $4.1 \mathrm{a}$ & $13.9 \mathrm{c}$ & -16.49 & -11.16 & -43.20 \\
\hline Vinasse $+4 \mathrm{~T}+$ clayey soil & $5.40 \mathrm{a}$ & $26.19 \mathrm{a}$ & $9.34 \mathrm{a}$ & $3.97 \mathrm{a}$ & $14.5 \mathrm{a}$ & $4.6 \mathrm{a}$ & $7.1 \mathrm{c}$ & -16.91 & -10.42 & -50.76 \\
\hline Vinasse $+2 \mathrm{~T}+$ sandy soil & $4.17 \mathrm{~b}$ & $4.08 \mathrm{c}$ & $3.38 \mathrm{c}$ & $1.00 \mathrm{~b}$ & $10.3 \mathrm{a}$ & $1.3 \mathrm{c}$ & $78.1 \mathrm{~b}$ & -12.76 & -7.67 & 15.10 \\
\hline Vinasse $+4 \mathrm{~T}+$ sandy soil & $4.53 \mathrm{~b}$ & $3.15 \mathrm{c}$ & $3.07 \mathrm{c}$ & $1.93 \mathrm{~b}$ & $8.0 \mathrm{a}$ & $1.2 \mathrm{c}$ & $152.0 \mathrm{a}$ & -17.21 & -8.62 & 89.53 \\
\hline Water $+2 \mathrm{~T}+$ clayey soil & $5.20 \mathrm{a}$ & $28.41 \mathrm{a}$ & $9.49 \mathrm{a}$ & $3.97 \mathrm{a}$ & $25.4 \mathrm{a}$ & $3.6 \mathrm{~b}$ & $21.3 \mathrm{c}$ & 18.93 & 5.12 & 2.40 \\
\hline Water $+4 \mathrm{~T}+$ clayey soil & $4.47 \mathrm{~b}$ & $5.19 \mathrm{c}$ & $3.71 \mathrm{c}$ & $1.63 \mathrm{~b}$ & $6.8 \mathrm{a}$ & $1.4 \mathrm{c}$ & $132.7 \mathrm{a}$ & 26.41 & 5.51 & 7.40 \\
\hline Water $+2 \mathrm{~T}+$ sandy soil & $5.30 \mathrm{a}$ & $27.11 \mathrm{a}$ & $9.46 \mathrm{a}$ & $1.13 \mathrm{~b}$ & $10.9 \mathrm{a}$ & $3.1 \mathrm{~b}$ & $6.4 \mathrm{c}$ & 8.86 & 5.17 & 1.10 \\
\hline Water $+4 \mathrm{~T}+$ sandy soil & $5.27 \mathrm{a}$ & $29.15 \mathrm{a}$ & $10.18 \mathrm{a}$ & $1.20 \mathrm{~b}$ & $17.4 \mathrm{a}$ & $3.0 \mathrm{~b}$ & $11.2 \mathrm{c}$ & 11.77 & 6.44 & 0 \\
\hline Vinasse + sandy soil & $4.17 \mathrm{~b}$ & $5.01 \mathrm{c}$ & $3.60 \mathrm{c}$ & $0.40 \mathrm{c}$ & $3.5 \mathrm{a}$ & $0.6 \mathrm{~d}$ & $3.2 \mathrm{c}$ & -14.97 & -7.39 & 70.13 \\
\hline Vinasse + clayey soil & $4.13 \mathrm{~b}$ & $3.34 \mathrm{c}$ & $2.99 \mathrm{c}$ & $0.37 \mathrm{c}$ & $1.6 \mathrm{a}$ & $0.2 \mathrm{~d}$ & $2.5 \mathrm{c}$ & 1.63 & -9.28 & -35.90 \\
\hline Water + clayey soil & $5.17 \mathrm{a}$ & $26.36 \mathrm{a}$ & $9.24 \mathrm{a}$ & $1.10 \mathrm{~b}$ & $14.5 \mathrm{a}$ & $2.6 \mathrm{~b}$ & $8.8 \mathrm{c}$ & 17.22 & 3.38 & 4.53 \\
\hline Water + sandy soil & $4.2 \mathrm{~b}$ & $5.19 \mathrm{c}$ & $3.37 \mathrm{c}$ & $0.47 \mathrm{c}$ & $2.9 \mathrm{a}$ & $0.5 \mathrm{~d}$ & $2.7 \mathrm{c}$ & 14.75 & 6.26 & 0.07 \\
\hline Clayey soil & $5.53 \mathrm{a}$ & $18.79 \mathrm{~b}$ & $7.30 \mathrm{~b}$ & $2.20 \mathrm{~b}$ & - & - & - & - & - & - \\
\hline Sandy soil & $4.03 \mathrm{~b}$ & $1.04 \mathrm{c}$ & $0.54 \mathrm{~d}$ & $2.10 \mathrm{~b}$ & - & - & - & - & - & - \\
\hline
\end{tabular}

Different lowercase letters in the same column represent significantly different means $(\mathrm{p}<0.05$ by the Scott-Knott test).
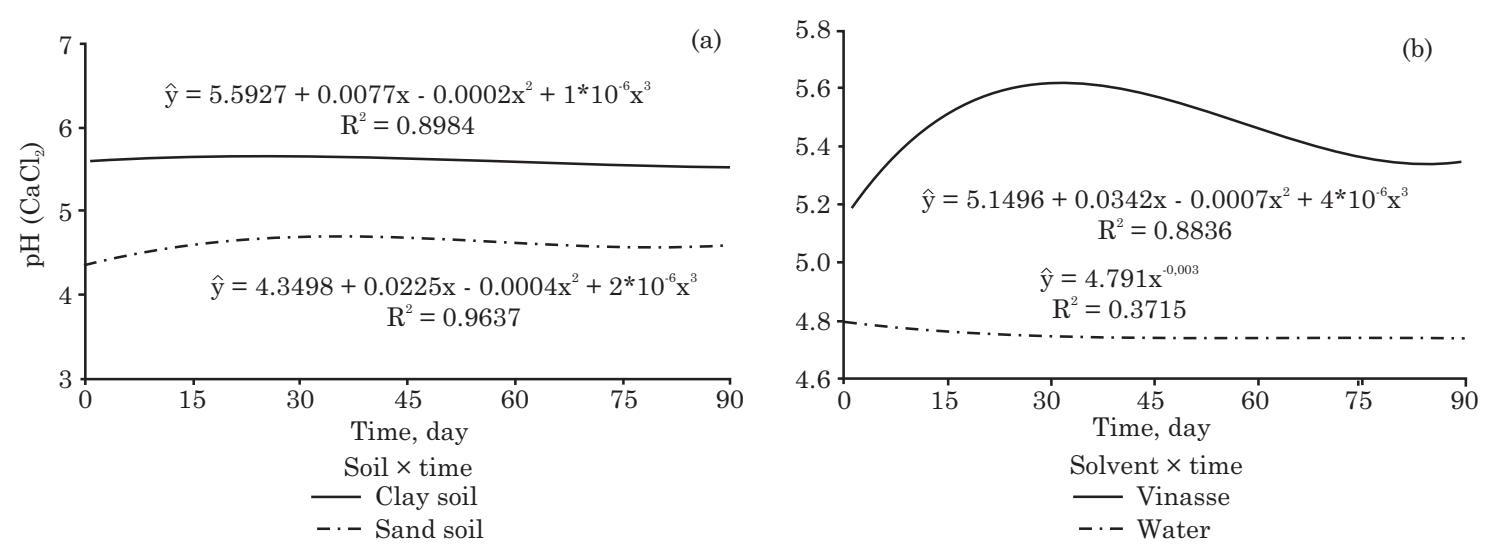

Figure 4. Levels of $\mathrm{pH}$ in $\mathrm{CaCl}_{2}$ based on time, soil type (Red Oxisol - clayey soil and Typic Quartzipsamment - sandy soil) and vinasse application: (a) Soil $\times$ time interaction; (b) Solvent $\times$ time interaction.

These results were similar to those obtained by Silva et al. (2012) testing the incubation of various types of rock powders with Yellow Latosol soil material from the 0-20 cm layer over 100 days. They found that ultramafic rock powder led to an increase in available $\mathrm{Ca}^{2+}, \mathrm{Mg}^{2+}$ and $\mathrm{K}^{+}$concentrations in the soil. According to the authors, the higher releases of these nutrients was related to the mineralogical composition of the ultramafic rock, with pyroxenes providing $\mathrm{Ca}^{2+}$ and $\mathrm{Mg}^{2+}$, and feldspars providing $\mathrm{Ca}^{2+}, \mathrm{Mg}^{2+}$, and $\mathrm{K}^{+}$. In another study, Welter et al. (2011) evaluated the initial development of camu-camu (Myrciaria dubia) seedlings using different application rates of basalt powder $\left(0,0.42,1.04,2.08,4.17\right.$, and $\left.8.33 \mathrm{~g} \mathrm{~kg}^{-1}\right)$, two particle sizes (0.05 and $0.10 \mathrm{~mm}$ diameter) and one control. The treatments without basalt powder and at an application rate of $0.42 \mathrm{~g} \mathrm{~kg}^{-1}$ produced the lowest quality seedlings at both particle sizes tested. The highest quality seedlings were obtained in the treatments with 4.17 and $8.33 \mathrm{~g} \mathrm{~kg}^{-1}$ basalt powder with the $0.05 \mathrm{~mm}$ particle size. Welter et al. (2011) affirmed that the quickest nutrient availability at finer particle sizes and higher nutrient contributions occurred when a greater amount of basalt powder was applied. These results confirmed the role that silicate rock powders can have in the provision of nonnegligible quantities of soluble cations, even after a relatively short incubation period in the soil. 
In the balance between the beginning and the end of the experiment with vinasse and rock powder in clayey soil (Table 3), a deficit of $\mathrm{Ca}^{2+}, \mathrm{Mg}^{2+}$, and $\mathrm{K}^{+}$ was observed. In the treatments with vinasse and rock powder in sandy soil, there was a deficit of $\mathrm{Ca}^{2+}$ and $\mathrm{Mg}^{2+}$ and an increase in $\mathrm{K}^{+}$, proportional to the rate of rock powder applied. The decrease in the number of soluble cations in a closed system can be attributed to the sorption process from both organic acids present in the vinasse and by new mineral phases produced due to the alteration processes of minerals contained in the rock powder. The term sorption is used here according to Dick et al. (2009), as it is more generic and non-specific, covering phenomena such as adsorption and precipitation, including the formation of new structures on existing surfaces.

Some studies have found that silicate rock powders can generate mineral phases of high reactive capacity through soil alteration processes. Camargo et al. (2012) aimed to evaluate the desirable agronomic characteristics of strawberries subjected to different application rates of bovine manure and basalt powder. Treatments with 0,50 , and 100 tha $^{-1}$ bovine manure, and $0,2,4$, and 6 t ha $^{-1}$ basalt powder were used. The researchers observed that the yield and the commercial fruit production improved when high application rates of bovine manure and intermediary application rates of basalt powder were used. According to these authors, the results obtained for rock powder occurred because this material provided electronegative colloids to the soil and thus made $\mathrm{Ca}^{2+}, \mathrm{Mg}^{2+}$, and $\mathrm{K}^{+}$ adsorption possible, preventing their movement into the soil. Meanwhile, Melo et al. (2012) evaluated the effect of applying different rates of basalt to a Red Oxisol and observed that there were no high increments of $\mathrm{Ca}^{2+}$ and $\mathrm{Mg}^{2+}$ since these ions are found in minerals of low solubility and slow alteration.

The basalt powder used in this study was provided by a quarry that incorporates intrusive rock formations in the form of sills and dikes, associated with the Serra Geral volcanism in the western region of the Paraná basin in the State of São Paulo. Petrographic data from Machado et al. (2005) showed that the rocks studied are essentially constituted of plagioclases, pyroxenes and opaque minerals. These minerals exhibited different types of crystalline structures with different alteration speeds and releases of ions in the soil. Some mineral alteration reactions can reduce the availability of cations in the soil through the precipitation of $\mathrm{Al}$ polymers and the neoformation of minerals from cation adsorption in $\mathrm{Fe}$ and $\mathrm{Al}$ oxides and hydroxides (surface complexes and specific adsorption) and the fixation of cations in chlorinated minerals, montmorillonite, and vermiculite (Escosteguy \& Klamt, 1998).

In regard to cation balance, the absence of rock powder within the vinasse treatments also led to a negative balance in both soils, with the exception of $\mathrm{Ca}^{2+}$ in the clayey soil, which presented a very slight increase. In contrast, an increase in the cations studied was observed in the treatments with water and the absence of rock powder in both soils, with the exception of $\mathrm{K}^{+}$in the sandy soil, where the balance was considered null. These results, apparently contradictory, suggested that the organic acids from vinasse could be complexing the cations.

As a soil fertilization technique, stone meal mainly uses quarry and mining residues and has been highlighted as being important in the remineralization of soils by its residual effect. Bakken et al. (2000) conducted an experiment using treatments with $\mathrm{KCl}$, two carbonatites, and three mining residues containing biotite, K-feldspar, and nepheline as potash fertilizers in experimental grass fields over four years. In the first and second years of the experiment, the $\mathrm{KCl}$ treatment had a greater yield than the treatments with rock powder, but in the third and fourth years, when potash fertilizer was not applied, grass growth in both the carbonatite and biotite treatments was similar to the treatment with $\mathrm{KCl}$. (Bakken et al., 2000). Another important application is the use of stone meal in recovering degraded areas. Silva et al. (2008) investigated the effects of basalt powder and different organic residues on the chemical and microbiological aspects of a bare subsoil and on the growth of Gonçalo Alves (Astronium fraxinifolium Schott). The authors found that stone meal showed positive effects on the chemical quality of subsoil after 165 days of incubation and that the application of different rates of sewage sludge to the basalt favored the growth of Gonçalo Alves.

Vinasse is primarily a liquid effluent generated from sugarcane-ethanol industries in the manufacturing of alcohol and spirits. It can promote the dispersion of soil particles with reduction in the rate of water infiltration in the soil and elevation of surface runoff, with possible contamination of surface waters (Matos et al., 2013). In addition, the use of vinasse and rock powder in agriculture is particularly important, due to the increasing production of these residues and the need to undertake reverse logistics of these materials to meet the requirements of Law No. 12305/2010 - National Solid Waste Policy (Política Nacional de Resíduos Sólidos) (Brasil, 2010).

The use of vinasse together with silicate rock powder can accelerate alteration of the minerals contained in the powder and release cations which remain adsorbed in neoformed mineral phases or which formed soluble complexes with organic acids. Up to now, agronomic studies have predominantly focused on the potential of rock powder for providing important elements for plant nutrition, often with the expectation of a rapid effect in comparison to the process of rock weathering. The present study also had this objective, although the data obtained indicated that mixing vinasse and rock powder can have an important effect as a soil conditioner, with a possible increase in permanent ionic charges. This aspect should, however, be further studied. 


\section{CONCLUSIONS}

1. In the 90 days of the experiment with soils of contrasting texture (clayey soil and sandy soil), there was a significant effect of the solvent and type of soil on the $\mathrm{pH}$ and the levels of $\mathrm{Ca}^{2+}, \mathrm{Mg}^{2+}$, and $\mathrm{K}^{+}$in the surface layer. The highest levels were measured in the treatments with vinasse in clayey soil, confirming the potential of vinasse to alter the minerals contained in the basalt powder.

2. In the balance of levels measured at the beginning and the end of the experiment in two soil layers (topsoil and subsoil) and in leaching, there was a decrease in the quantity of available cations studied, suggesting that sorption phenomena with neoformed minerals or with organic acids may have occurred.

3. The mixture of vinasse and rock powder may be an alternative for soil fertilization, and may be an important option for reuse of residues from the alcohol production and mining industries. Additional studies are recommended to evaluate sorption phenomena that may occur when this mixture is applied to the soil.

\section{LITERATURE CITED}

BAKKEN, A.K.; GAUTNEB, H.; SVEISTRUP, T. \& MYHR, K. Crushed rocks and mine tailings applied as $\mathrm{K}$ fertilizers on grassland. Nutr. Cycl. Agroecosyst., 56:53-57, 2000.

BRASIL. Política Nacional de Resíduos Sólidos (Lei nº.12.305/ 2010). Brasília. Diário Oficial da União, 2010. Available at: <http://www.planalto.gov.br/ccivil_03/_ato2007-2010/ 2010/lei/112305.htm>. Accessed: Feb. 12, 2013.

CAMARGO, O.A.; MONIZ, A.C.; JORGE, J.A. \& VALADARES, J.M.A.S. Métodos de análise química, mineralógica e física de solos do Instituto Agronômico de Campinas. Campinas, Instituto Agronômico, 2009. 77p.

CAMARGO, C.K.; RESENDE, J.T.V.; CAMARGO, L.K.P.; FIGUEIREDO, A.S.T. \& ZANIN, D.S. Produtividade do morangueiro em função da adubação orgânica e com pó de basalto no plantio. Semina: Ci. Agrár., 33:2985-2994, 2012.

CASAGRANDE, J.C. \& SOARES, M.R. Modelos químicos de adsorção. In: MELO, V.F.; ALLEONI, L.R.F., eds. Química e mineralogia do solo: Parte 2 - Aplicações. Viçosa, MG, Sociedade Brasileira de Ciência do Solo, 2009. p.131-160.

DICK, D.P.; NOVOTNY, E.H.; DIECKOW, J. \& BAYER, C. Química da matéria orgânica do solo. In: MELO, V.F. \& ALLEONI, L.R.F., eds. Química e mineralogia do solo: Parte 2 - Aplicações. Viçosa, MG, Sociedade Brasileira de Ciência do Solo, 2009. p.1-68.

EMPRESA BRASILEIRA DE PESQUISA AGROPECUÁRIA EMBRAPA. Sistema brasileiro de classificação de solos. 2.ed. Rio de Janeiro, Embrapa Solos, 2013. 353p.
ESCOSTEGUY, P.A.V. \& KLAMT, E. Basalto moído como fonte de nutrientes. R. Bras. Ci. Solo, 22:11-20, 1998.

GUDBRANDSSON, S.; WOLFF-BOENISCH, D.; GISLASON, S.R. \& OELKERS, E.H. An experimental study of crystalline basalt dissolution from $2 \leq \mathrm{pH} \leq 11$ and temperatures from 5 to $75{ }^{\circ} \mathrm{C}$. Geochim. Cosmochim. Acta, 75:5496-5509, 2011.

HARLEY, A.D. \& GILKES, R.J. Factors influencing the release of plant nutrient elements from silicate rock powders: A geochemical overview. Nutr. Cycl. Agroecosyst., 56:1136, 2000.

KÄMPF, N.; CURI, N. \& MARQUES, J.J. Intemperismo e ocorrência de minerais no ambiente do solo. In: MELO, V.F. \& ALLEONI, L.R.F., eds. Química e mineralogia do solo: Parte 1 - Conceitos básicos. Viçosa, MG, Sociedade Brasileira de Ciência do Solo, 2009. p.333-380.

LOPES, O.M.M. Efeito de agromineral e vinhaça em atributos químicos de dois tipos de solos. São Carlos, Universidade Federal de São Carlos, 2013. 125p. (Dissertação de Mestrado)

LOPES, O.M.M.; COSTA, L.G. \& LOPES-ASSAD, M.L. Disponibilização de nutrientes em misturas de pó de rocha com vinhaça. In: CONGRESSO BRASILEIRO DE CIÊNCIA DO SOLO, 33., Uberlândia, 2011. Anais... Uberlândia, Sociedade Brasileira de Ciência do Solo, 2011. CD-ROM

LOURENÇO JÚNIOR, B.A. Desenvolvimento de laranjeira 'Pêra' (Citrus sinensis (L.) Osbeck) enxertada em limoeiro 'Cravo' (Citrus limonia) e cultivada com pó de basalto. Botucatu, Universidade Estadual Paulista, 2011. 87p. (Dissertação de Mestrado)

MACHADO, F.B.; NARDY, A.J.R.; MELO, R.P.; OLIVEIRA, M.A.F. \& SQUISATO, E. As rochas intrusivas da formação Serra Geral na porção leste da Bacia do Paraná no estado de São Paulo: Aspectos petrográficos e geoquímicos - resultados preliminares. Geociências, 24:517, 2005.

MATOS, A.T.; GARIGLIO, H.A.A. \& LO MONACO, P.A.V. Deslocamento miscível de cátions provenientes da vinhaça em colunas de solo. R. Bras. Eng. Agríc. Amb., 17:743749, 2013.

McMAHON, P.B.; VROBLESKY, D.A.; BRADLEY, P.M.; CHAPELLE, F.H. \& GULLETT, C.D. Evidence for enhanced mineral dissolution in organic acid-rich shallow ground water. Ground Water, 33:207-216, 1995.

MELO, V.F.; UCHÔA, S.C.P.; DIAS, F.O. \& BARBOSA, G.F. Doses de basalto moído nas propriedades químicas de um Latossolo Amarelo distrófico da savana de Roraima. Acta Amaz., 42:471-476, 2012.

PAVINATO, P.S. \& ROSOLEM, C.A. Disponibilidade de nutrientes no solo - decomposição e liberação de compostos orgânicos de resíduos vegetais. R. Bras. Ci. Solo, 32:911920, 2008.

RAIJ, B.van; ANDRADE, J.C.; CANTARELLA, H. \& QUAGGIO, J.A. Análise química para avaliação da fertilidade de solos tropicais. Campinas, Instituto Agronômico, 2001. 285p. 
RASMUSSEN, C.; DAHLGREN, R.A. \& SOUTHARD, R.J. Basalt weathering and pedogenesis across an environmental gradient in the southern Cascade Range, California, USA. Geoderma, 154:473-485, 2010.

RIBEIRO, L.S.; SANTOS, A.R.; SOUZA, L.F.S. \& SOUZA, J.S. Rochas silicáticas portadoras de potássio como fontes do nutriente para as plantas. R. Bras. Ci. Solo, 34:891-897, 2010.

SAS Institute Inc. SAS/STAT user's guide. Version. 9.3. Cary, 2011.

SILVA, E.A.; CASSIOLATO, A.M.; MALTONI, K.L. \& SCABORA, M.H. Efeitos da rochagem e de resíduos orgânicos sobre aspectos químicos e microbiológicos de um subsolo exposto e sobre o crescimento de Astronium fraxinifolium Schott. R. Árvore, 32:323-333, 2008.
SILVA, D.R.G.; MARCHI, G.; SPEHAR, C.R.; GUILHERME, L.R.G.; REIN, T.A.; SOARES, D.A. \& ÁVILA, F.W. Characterization and nutrient release from silicate rocks and influence on chemical changes in soil. R. Bras. Ci. Solo, 36:951-962, 2012.

SISTEMA AGRITEMPO. Available at: < http://www.agritempo. gov.br>. Accessed: Jul. 15, 2012.

WELTER, M.K.; MELO, V.F.; BRUCKNER, C.H.; GOES, H.T.P.; CHAGAS, E.A. \& UCHÔA, S.C.P. Efeito da aplicação de pó de basalto no desenvolvimento inicial de mudas de camu-camu (Myrciaria dubia). R. Bras. Frutic., 33:922-931, 2011.

YANG, Y.; MIN, Y. \& JUN, Y-S. Effects of Al/Si ordering on feldspar dissolution: Part II. The $\mathrm{pH}$ dependence of plagioclases' dissolution rates. Geochim. Cosmochim. Acta, 126:595-613, 2014. 